\title{
パワーレーザーを用いた強磁場発生
}

\author{
藤岡慎介, 森田大樹, 松尾一輝, King Fai Farley LAW, Chung LIU, \\ 李昇浩, 安部勇輝, 坂田 匠平 \\ 大阪大学レーザー科学研究所 (†565-0871 大阪府吹田市山田丘 2-6)
}

\section{Generation of Strong Magnetic Field with High-Power Laser}

\author{
Shinsuke FUJIOKA, Hiroki MORITA, Kazuki MATSUO, King Fai Farley LAW, Chung LIU, \\ Seung Ho LEE, Yuki ABE, and Shohei SAKATA \\ Institute of Laser Engineering, Osaka University, 2-6 Yamadaoka, Suita, Osaka 565-0871
}

(Received May 23, 2019)

\begin{abstract}
With the increase in intensity and energy of high-power lasers, it became possible to generate kiloteslaclass magnetic fields that can be applied to high-energy-density physics experiments. The application of magnetic field broadens the interdisciplinary sciences covered by the high-energy-density-physics. In this article, we will introduce the generation of a strong magnetic field with a capacitor-coil and a sail targets driven by a high-power laser. Kilotesla magnetic field improves the quality of fast electron and ion beams produced by a high-power laser. We describe hydrodynamic instability caused by the anisotropy of thermal conduction in the external magnetic field, and the relativistic magnetic reconnection and particle acceleration associated with reconnection in high energy magnetized plasma, and finally, the challenge to $10 \mathrm{kT}$ will be discussed.
\end{abstract}

Key Words: High-power-laser, Strong magnetic field, High-energy-density physics, Capacitor-coil target, Snail target

\section{1. はじめに}

短時間 $(\mathrm{ps}-\mathrm{ns})$ かつ微小空間 $(<\mathrm{mm})$ に大きなエネル ギーを集中できるパルス・レーザーを物質に照射するこ とで，単位体積当たりのエネルギー(=エネルギー密度 $)$ が大きい，高エネルギー密度状態を作ることができる． 高エネルギー密度状態の物質又はプラズマは, レーザー 照射による材料改質及び半導体リソグラフィー用の極端 紫外光源として産業界で既に実用化され，更に高輝度パ ルス及びコヒーレントX 線源, 電子 ・ イオン源, 中性 子源としての研究開発が進められている。学術面では恒 星及び惑星内部の超高圧下における物質状態の科学, 太 陽表面のフレアからの高エネルギー粒子加速機構である 磁気リコネクション，宇宙における高エネルギー粒子加 速メカニズムである無衝突衝撃波などと共通の物理を内 包しており, 高エネルギー密度科学は多様な学際的研究 の宝庫である.
2.レーザー駆動キャパシタ・コイルによる

磁場発生機構

高エネルギー密度物質はエネルギー変換媒体としての 機能も有する、コイルの形をした物質を高エネルギー密 度化することで，レーザーのエネルギーを効率的に磁場 に変換することができる, 我々の研究グループでは, キャ パシタ・コイル・ターゲット1)及びスネール・ターゲッ ト2) と呼ばれるレーザー標的を用い, キロテスラ級の強 磁場を発生させることに成功している。

Fig. 1 に示すように, キャパシタ・コイル・ターゲッ トは，平行に並べた二枚の金属円板を，円環状のワイヤ で接続したものである。一方の金属円板にハイパワー レーザーを照射し，ワイヤに電流を駆動する。キャパシ タ・コイル・ターゲットを用いた磁化プラズマの実 験 ${ }^{3-10)}$ が行われている一方で, 強磁場の発生メカニズム のモデル構築は未完成である。なお，電子のサイクロト ロン周波数が電子 - イオン衝突周波数を上回る状態のプ ラズマを磁化プラズマと呼ぶ.

最初に提唱されたのは, Fig. 1 に示すように, レーザー プラズマ相互作用によって生成された高エネルギー電子 


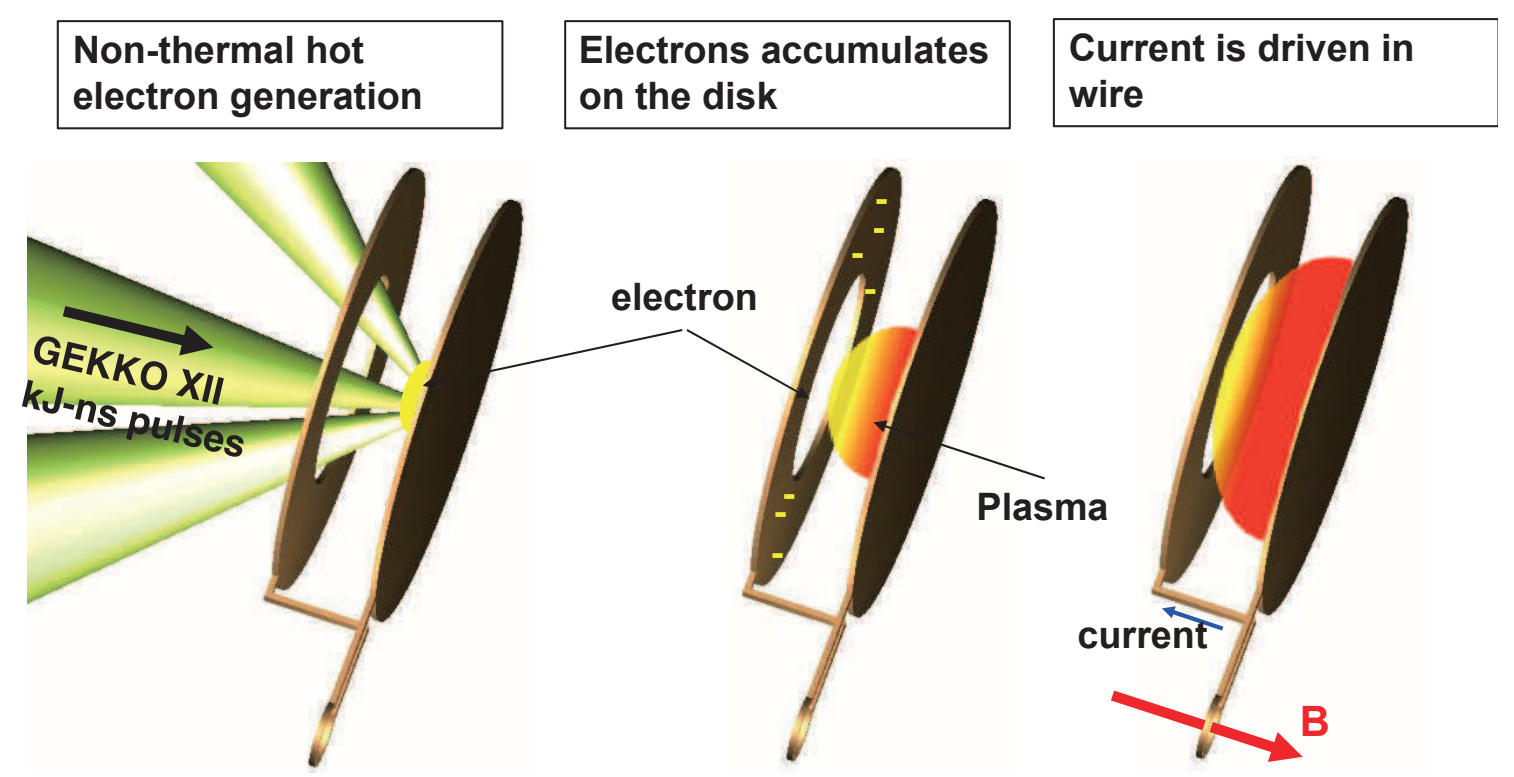

Fig. 1 Magnetic field generation with a capacitor-coil target. According to a model, potential difference is produced by the hot electrons flow between the two disks, however, recent experimental results support another model, in which the current is produced by the plasma flow between the disks.

が，他方の金属円板に蓄積することで金属板間に電位差 が生じ，ワイヤーに電流が駆動されるというモデルであ る11-13)。このモデルによると，電子が極板間を移動す るナノ秒以下の時間で電位差が形成され，コイルに電流 が流れる時間は回路の抵抗とインダクタンスで決まるた め, 磁場のパルス幅はレーザーパルス幅に依存しないこ とになる。2017 年及び 2018 年に米国ロチェスター大学 の OMEGA-EP レーザーにて，照射レーザーの強度を固 定したまま, パルス幅を $0.75 \mathrm{~ns}$ から $10 \mathrm{~ns}$ まで変える と, 磁場のパルス幅がレーザーパルス幅に追従して伸び るという実験結果が得られた。この実験結果は上述のモ デルでは説明できない。レーザーが照射され続けている 間，二枚の金属板間を満たすプラズマ中に電流が生じる という新しいモデル14)を支持する結果である.

この新しいモデルも完全では無く, 実験で観測されて いる磁場強度の時間変化を説明できない. モデルと実験 結果の不一致の原因と着目しているのが，（1）コイル材 質の導電率の温度依存性, (2) コイル断面での電流密度 分布の時間変化の 2 つである。コイル断面における電流 密度分布の時間変化は, 導電率の温度依存性に依存する。 したがって, 導電率の温度依存性を考慮した時間依存の 電磁場解析コードの開発が, 実験結果の解析や長パルス におけるレーザー駆動コイルのモデル構築において重要 な課題である。

$\mathrm{kT}$ 級の強磁場が生成されている間, コイルには $100 \mathrm{kA}$ 相当の電流が流れている。この電流はジュール 加熱によってコイル材を数万度に達する高温状態にまで 加熱する。数万度の温度を有する固体物質は, Warm Dense Matter(WDM) と呼ばれる状態にある。WDM 状態 は物質の非結晶性と原子の部分電離が混在した, 固体と プラズマの中間状態である。この状態ではクーロン相互 作用や電子縮退の効果が顕著に現れるため, 従来の固体
物理やプラズマ物理の理論が適用できない，WDM 状態 に拈ける導電率の温度依存性を調べるために，第一原理 計算手法である Quantum Molecular Dynamics (QMD)を用 いた。

Fig. 2 は固体密度の金における導電率の温度特性を表 している。金の導電率は沸点 $0.27 \mathrm{eV}$ までは温度ととも に下がることが実験的に確認されている。沸点以上の導 電率は，計測が困難であることから実験的に詳しく調べ られていない，修正 Spitzer モデル15)によると，金の導 電率は沸点に達すると急激に下降し， $1 \mathrm{eV}$ 付近までは

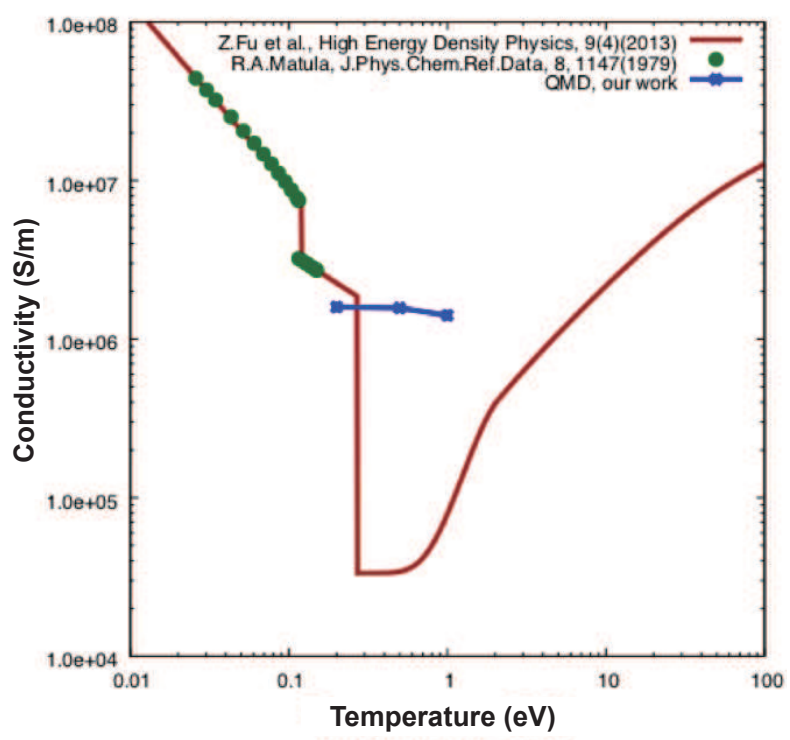

Fig. 2 The conductivity of gold in the warm dense matter regime. The circles are experimental results and the solid line is a calculation with the modified Spitzer model. The crosses are our calculation with QMD scheme. 
絶縁体のように振る舞うと予測されている. 対して QMD の計算結果は 0.2, $0.5,1 \mathrm{eV}$ の各温度において, 金は $10^{6} \mathrm{~S} / \mathrm{m}$ 程度の導電率を保っているという結果を示 している。我々は，WDM 状態にある物質の電気伝導率 をモデルに組み込み、キャパシタ・コイルターゲットで 生成される磁場強度の空間及び時間変化を計算するシ ミュレーション・コードの開発に取り組んでいる. 現在 のところ，開発したシミュレーション・コードを使って， 実験で観測された磁場の空間分布は再現できているが, 時間変化はまだ定性的な一致に留まっている。この取り 組みの一部は学術論文として発表している16).

\section{3. キャパシタ・コイル・ターゲットを用いた} 高エネルギー密度磁化プラズマ研究の進展

レーザー駆動方式によってキロテスラ級の磁場が実現 するまでは, 外部から印加される磁場の圧力はプラズマ の圧力よりも遙かに小さく, 外部から印加された磁場が 高エネルギー密度プラズマの主たるダイナミクスに与え る影響は小さかった。 最近の研究では, 外部磁場によっ てプラズマ中での熱伝導が非等方になることによって, 高エネルギー密度プラズマのダイナミクスが変化するこ とも明らかになっている。本章では，キャパシタ・コイ ル・ターゲットの利用によって拡大している磁化プラズ マ研究の進展について紹介する.

磁場を活用した高エネルギー密度科学研究の一例とし て, 最初に磁化高速点火 ${ }^{17)}$ の概略を述べる. 詳細は坂 田氏による解説論文をご覧頂きたい。磁化高速点火とは, 外部印加した強磁場とレーザー核融合高速点火を組み合 わせた核融合プラズマの加熱法である。高速点火方式は, 核融合燃料の圧縮と加熱の過程を分離することで, 核融 合点火に必要なエネルギーを低減する方法として提案さ れた。高速点火方式の一般的なシナリオでは，ペタワッ 卜級の高強度レーザーで加速した電子ビームで, 別途圧 縮した核融合燃料を加熱する。しかしながら，レーザー で加速された電子ビームは全角で 100 度程度の大きな発 散角を有しているため, 加速された電子ビームの大半は, 核融合燃料と衝突しないという障害を抱えていた。電子 ビームの発散角を低減するために, 電子ビームの伝播領 域に外部から縦磁場を印加する「磁化高速点火」が提案さ れた17-19)

磁場中に存在する電子は，磁力線周りを旋回運動する. 磁場の強度が上昇すると，その旋回半径は小さくなり， 磁力線に沿った方向には自由に動けるが, 磁力線を跨ぐ 方向には動けなくなる. 高速電子の発生点から核融合燃 料を繋ぐように, 強力な磁力線を張ることで, 高速電子 ビームの発散を抑え, 燃料に向けて誘導することが可能 である、レーザー駆動磁場を核融合燃料に印加すること で，加熱レーザーから核融合燃料へのエネルギー変換効 率を $8 \%$ まで上昇させることに成功した6). 加熱レー ザーのエネルギーの $15 \%$ 以上が加熱に寄与できるよう な最適化が可能である。

高速点火レーザー核融合のみならず，中心点火レー
ザー核融合にレーザー駆動磁場を応用する研究も行われ ている。例えば, Lawrence Livermore National Laboratory の National Ignition Facility (NIF) では，中心点火方式によ るレーザー核融合の研究が進められている。点火方 式では，重水素 -三重水素の混合ガスを低温固化して製 造した球殼を燃料に用いる。球殼の内側は，重水素と三 重水素のガスを含んでいる。均一なレーザー又はX 線 で球殼の表面を照射し圧縮することで，ホットスパーク と呼ばれる高温・低密度の重水素・三重水素プラズマを 中心部に形成する。最大圧縮時には，ホットスパークの 周囲を低温・高密度の重水素 · 三重水素の高密度燃料が 取り囲む構造が形成される。高温のホットスパークから 低温の燃料部に電子熱伝導によってエネルギーが損失す ることが，核融合点火に必要なエネルギーを増大させる 要因の一つである.

上述の磁化高速点火のメカニズムと同じょうに，強磁 場下では電子は磁力線を跨ぐ方向に運動出来なくなる. つまり，磁力線を跨ぐ方向への電子熱伝導が抑制される 強磁場による熱伝導の抑制によって, 核融合点火の条件 が緩和されることが，シミュレーションで予測されてい る20).このアイディアを実現する方法の一つとして, レーザー駆動キャパシタ・コイル・ターゲットが利用さ れている。間接照射型レーザー核融合で用いられる金属 円筒(ホーラム)がコイルを兼ねることで，間接照射によ る一様な燃料圧縮と，レーザー駆動方式による強磁場発 生を両立させると期待されている。米国ロチェスター大 学の OMEGA レーザーを用いて実験が進められ，100$200 \mathrm{~T}$ の磁場の発生に成功している ${ }^{9)}$. 現在, このホー ラム型コイルにNIFのレーザーを照射し，生成される 磁場強度の測定が行われている。

続いて, 高エネルギー密度プラズマの流体現象の応用 において障壁となっている流体力学的不安定性に対する 外部磁場の影響に関する研究を紹介する。強磁場下では 高エネルギー密度プラズマ中での電子熱伝導が非等方に なる。非等方になった結果, 高エネルギー密度プラズマ の流体運動が変化することがシミュレーションで示され た21)。物質の表面に高強度レーザーを照射すると，物 質表面は急激に加熱されプラズマ化し，表面の剥離つま りアブレーションが起こる.アブレーションされた物質・ プラズマは真空側に膨脹し, 物質表面から真空側に向 かって指数関数的に減少する密度分布を有する。一方, レーザーエネルギーは，レーザーの波長で決まる臨界密 度(固体密度の $1 / 100$ 程度) 程度の比較的低密度なプラズ マで吸収される。吸収点から固体表面には主に熱伝導で エネルギーが輸送されることから，圧力勾配は密度勾配 と逆の符号を有する。密度勾配と圧力勾配が逆であるた め, アブレーション・プラズマは流体力学的に不安定で ある。レーザー照射された物質の表面の擾乱の振幅は, レイリー・テイラー不安定性によって時間に対して指数 関数的に増大する.

アブレーションを伴う物質に外部から $100 \mathrm{~T}$ の磁場を 印加し，物質表面の擾乱の成長を観測した。シミュレー ション及びモデルとの比較を容易にするために，波長及 
び振幅が既知の擾乱を印加したプラスチック薄膜に高強 度レーザーを照射した．X線バックライト法と X 線久 トリークカメラを組み合わせ, 擾乱振幅の時間変化を観 測した。アブレーションによるプラズマの流れと平行な 磁場を外部から印加すると, 流体不安定性の成長率が顕 著に増大することが観測された。これは，熱伝導の非等 方性によって，擾乱の谷にあたる部分の圧力が増大し， 逆に擾乱の山頂にあたる部分の圧力が低下することで, 擾乱の谷はより深く, 擾乱の山頂はより高くなることが 原因である4)。この実験条件に扔いては, 磁気圧はプラ ズマの圧力よりも十分低い. しかしながら, 熱伝導の非 等方性を介して, 流体運動が変化することを示すことが できた。

最後に, イオン加速へのレーザー駆動磁場の応用を述 べる、レーザーの高強度化により，レーザー加速による イオンビーム生成の研究が盛んに行われている。 しかし ながら，レーザー加速されるイオン種は水素(プロトン) が主であり, 粒子線癌治療や原子核物理学実験に求めら れる重元素のレーザー加速の研究は半ばである. 我々が 開発したキロテスラ級磁場と, 相対論的強度 $\left(>10^{18} \mathrm{~W} / \mathrm{cm}^{2}\right)$ のピコ秒レーザーを組み合わせ, 高価数 の重粒子ビームを効率的に加速することが可能であると 考えている.

レーザーイオン加速では，レーザーを薄膜に照射する． 最初に薄膜から生成されるプラズマ中の電子が光圧 (ポ ンデロモーティブカ) で加速され, 電子は薄膜から逃走 する, 逃走電子によって, 薄膜表面に電場が形成され, 薄膜の表面に水や油脂として付着しているプロトンが, この電場で加速される. 水や油脂が加速し尽くされた後 に, 薄膜を構成している他元素が加速される. プロトン は $Z / A=1$ であるため極めて加速されやすい.ここで $Z$ は電離価数, $A$ は質量数である. 薄膜中の重元素を加速 するためには，(1)プロトン加速後も電場を維持するた め, 長時間にわたりレーザーを薄膜に照射し続けること， (2) 加速前に重元素を高価数に電離して Z/A を大きくす ること, (3) 逃走電子を局所的に閉じ込め加速電場を大
きくすることが必要である.

（1）と（2）の条件を実現するには，加速レーザーの長パ ルス化が有効である。従来，レーザー加速に用いられて いたパルス幅は $1 \mathrm{ps}$ 以下であったが，大型レーザー装 置に拀いて，1 ps 以上のパルス幅で $\mathrm{PW}$ を越えるパワー が実現している，パルス幅が伸びるにしたがって，加速 電場が維持される時間も伸長する。加えて, レーザーと 薄膜の相互作用面からの熱伝導によって, 数 ps の時間 スケールで薄膜の固体密度領域も加熱され(熱拡散加 熱22)，高価数に電離することが数值シミュレーション で予測されている。

(3)の条件を実現するため, 磁場を利用する。 プロ卜 ン源となるターゲットに垂直な磁力線を印加することで, レーザー加速電子が横方向に広がることを抑制し，逃走 電子を局所的に閉じ込めることができる，閉じ込められ た電子は, ターゲットの表面と裏面を往復するうちに, 何度もレーザーからエネルギーを受け取り高エネルギー 化する，外部磁場を印加することで，加速イオンが高工 ネルギー化することは，シミュレーションで予測されて おり ${ }^{23)}$ ，現在その実証実験を進めている最中である.

\section{4. スネール・ターゲットを用いた磁場発生}

スネール・ターゲットは, ロシア核科学研究大学の Philipp Korneev 博士が提案した磁場生成ターゲットであ る. Fig. 3(a) はスネール・ターゲットの模式図と写真で ある. Fig. 3(b) は磁場発生のメカニズムを模式的に示し ている，高強度レーザーの振動電場によって電子が高工 ネルギーにまで加速され，ターゲットの外部に放出され る，局所的に電子が欠乏すると，電荷中性を保つために， 周囲からレーザー照射点に向けて電子が流れる (return current). 同時に, スネール・ターゲットの内面で, レー ザーは反射を繰り返しながら電子を加速する(surface current)。この二つの電流の和 (net current)で磁場が形成 される. Fig. $3(\mathrm{c})$ は実験結果から再構成した磁場の空間 分布である, スネール・ターゲットの内部には, 反平行

\section{(a) Snail target drawing and photograph}

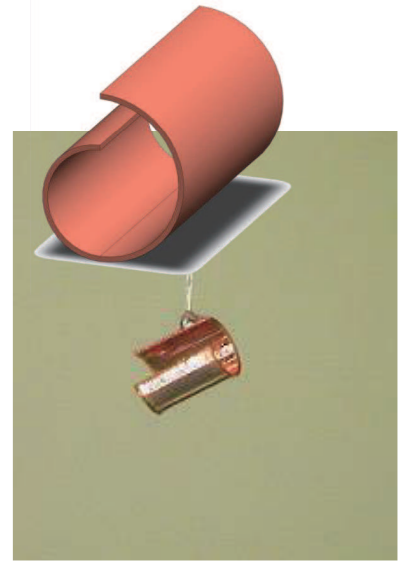

(b) Magnetic field generation mechanism

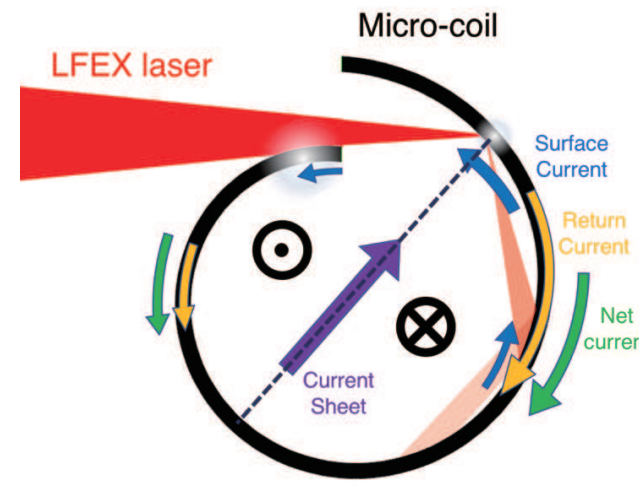

(c) Magnetic field profile reconstructed from proton radiograph.

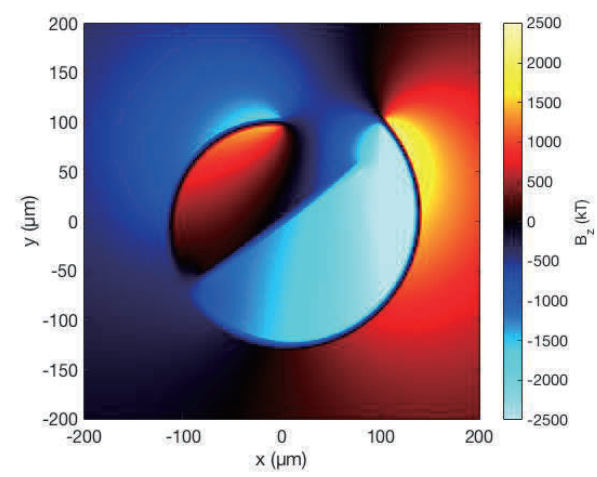

Fig. 3 Magnetic field generation with snail target irradiated by high-intensity laser. 
のキロテスラ級の磁場が形成される. 反平行の磁場の境 界には電流シート (current sheet) が形成される。直径 $300 \mu \mathrm{m}$ のスネール・ターゲットに, 大阪大学レーザー 科学研究所の LFEX レーザーの 1 ビーム $(0.5 \mathrm{~kJ}, 1 \mathrm{ps})$ を 照射し， $2.1 \mathrm{kT} の$ 磁場が生成されていることを測定し た24)

スネール・ターゲットの内部には，互いに反対向きで, 円筒の中心軸に平行な磁力線が共存し，かつ円筒の中心 軸に向かうプラズマの流れが存在する。このような状況 下では, この反平行の磁力線のつなぎ替え, つまり磁気 リコネクションが起こり, 磁場のエネルギーがプラズマ に散逸されることで, 高エネルギーの電子及び $Z / A=1$ のプロトンが優先的に加速されると予測される。我々は, 磁気リコネクションによる加速が生じる方向，つまり円 筒の中心軸に沿った方向に, 電子及びイオンのエネル ギー分析器を置き, 幕乗エネルギー分布を持った電子及 びプロトンがジェット状に加速される様子を観測するこ とに成功した。この観測結果は，2 次元及び 3 次元の粒 子シミュレーションでも再現された24).

実験結果とシミュレーション結果を組み合わせ，本実 験で生成したプラズマの磁化率(プラズマのエネルギー と磁場のエネルギーの比)とアルフベン速度を計算した。 一例として中心にブラックホールを持つと考えられてい る Cygnus X-1 の周囲に存在する降着円盤のコロナの上 記值を比較したところ，両者が非常に近いことが明らか になった。つまり，この実験では, Cygnus X-1で起こっ ていると予測されている磁気リコネクションの一側面を 実験室内で再現出来たことを意味する。実際，実験室内 で発生したリコネクションに伴って加速された電子の工 ネルギー分布の形状は, Cygnus X-1 から放射させるX 線スペクトルを説明するために推定された電子のエネル ギー分布と全く相似であった。つまり，Cygnus X-1 か ら放射される高エネルギーのX線を説明する電子加速 の機構として, 磁気リコネクションが有力な候補である
ことを実験的に示すことに成功した，更に実験データを 蓄積することが, Cygnus X-1 からの硬 X 線放射機構の 解明に繋がると期待される.

\section{5. $10 \mathrm{kT}$ 超の実現に向けて}

我々は一つの目標值として, $10 \mathrm{kT}$ の達成を掲げてい る. $10 \mathrm{kT} の$ 磁場中での電子サイクロトン周波数は, Nd:glass レーザーの $1.053 \mu \mathrm{m} の$ 光の周波数と等しい. つまり, $10 \mathrm{kT}$ の磁場中を運動する電子は, Nd:glass レー ザー光と共鳴的な相互作用をすると期待される。 また, $10 \mathrm{kT}$ の強磁場下での電子のサイクロトロン運動の軌道 周長は, 電子のド・ブロイ波長と同程度になり, 量子力 学的な効果が顕在化する. 電子の軌道周長が, ド・ブロ イ波長の整数倍しか許容されないため, 強磁場下では自 由電子が取り得る運動エネルギーは離散化する。この現

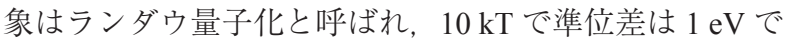
ある。更に $10 \mathrm{kT}$ の強磁場下では，ゼーマン効果も非線 形になる．主量子数と方位量子数が等しく磁気量子数が 異なる軌道のエネルギー縮退が磁場によって解けるのが ゼーマン効果である．弱い磁場による線形なゼーマン効 果は，磁場強度に比例したエネルギー幅で輝線が分離す る. $10 \mathrm{kT}$ の強磁場下では, 線形なゼーマン効果から予 測される分離幅は $1 \mathrm{eV} に も な り ，$ 可視光(光子エネル ギー〜2 eV) や真空紫外(光子エネルギー〜10 eV) 領域で は, 波動関数の磁場による変化を無磁場の波動関数の一 次摂動として扱うことができず，非線形な振る舞いが現 れる。中性子星のような極限磁場環境での磁場強度を精 緻に決定するために，ランダウ量子化及びゼーマン分離 が利用されるが，非線形ゼーマン分離については，水素 とへリウムの計算結果があるのみで実験的な測定はない そもそもリチウム以上の原子番号では計算結果すらない 次世代 X 線観測衛星は, 強磁場天体観測を視野に入れ ており, 高エネルギー分解能分光器を搭載する。非線形 (a)

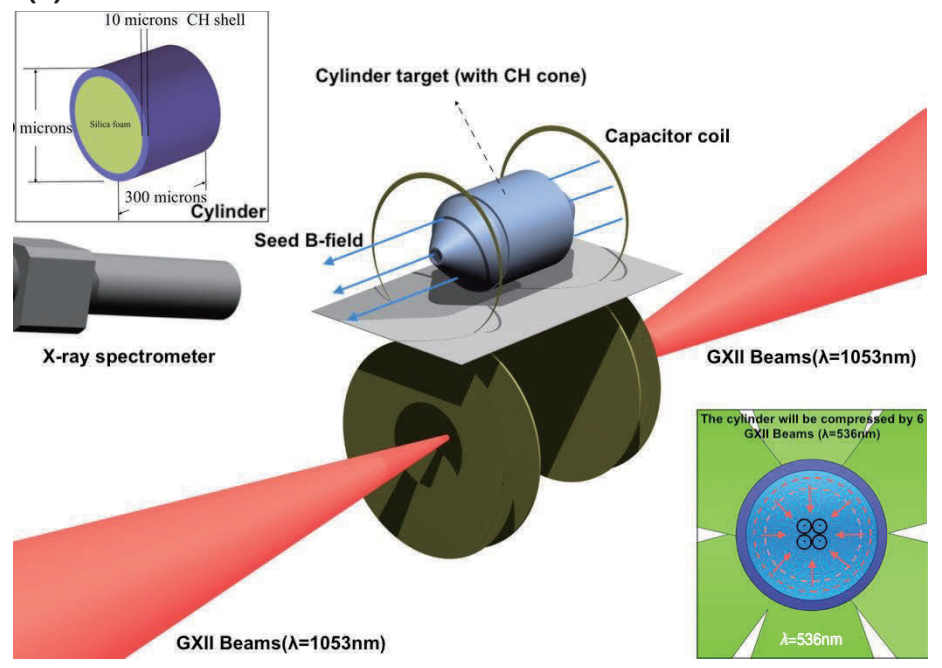

(b)

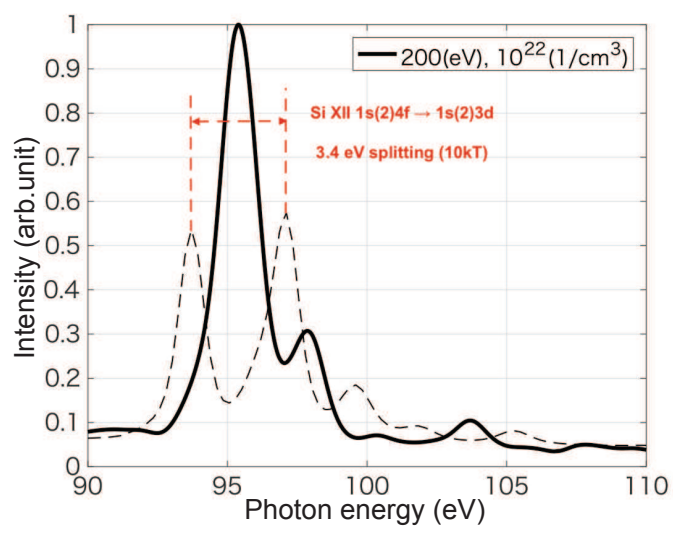

Fig. 4 Magnetic field compression by using laser-driven cylinder implosion. (a) Experimental setup and (b) computed $\mathrm{X}$-ray spectra emitted from unmagnetized (black solid line) and magnetized silicon plasmas (glay dashed line). 
ゼーマン効果によるスペクトル分離量を実験的に決定し ておくことは，X線天文学において欠かすことのできな い貴重なデータベースになると期待される。

$10 \mathrm{kT}$ を達成するための方法の一つとして, 上述のス ネール・ターゲットを考えている。 LFEXレーザーは 4 ビームで構成されており，スネール・ターゲットを照射 するレーザーのエネルギーは， $2.1 \mathrm{kT}$ を達成した実験と 比べて, 4 倍増大させることが出来る. 加えて, スネール. ターゲットの直径を $100 \mu \mathrm{m}$ に小さくすれば, $0.5 \mathrm{~kJ} / 1 \mathrm{ps}$ の LFEXレーザーでも，10 kTを達成出来ることを， シ ミュレーションで予測している，スネール・ターゲット を用いて, 本研究で必要な $10 \mathrm{kT}$ を実現出来る可能性は 高い.

もう一つは, キャパシタ・コイル・ターゲットで生成 した $1 \mathrm{kT}$ 程度の種磁場を円筒状のプラズマで圧縮する ことによって, $10 \mathrm{kT}$ を越える強磁場を達成する手法で ある.Fig. 4(a) は実験の模式図である. 2 個のキャパシ タ・コイル・ターゲットを対面に配置し, 一様な種磁場 を形成する。 2 個のキャパシタ・コイル・ターゲットの 中心付近に, 密度 $5 \mathrm{mg} / \mathrm{cm}^{3}$ の低密度酸化シリコン・ フォームを詰め込んだプラスチック円筒を置き, 円筒の 表面に高強度レーザーを集光照射し, 円筒をプラズマ化 すると同時に圧縮する。プラズマの圧縮に伴って, 磁場 も圧縮され, 中心部では $10 \mathrm{kT}$ を越える磁場が生成され ることを，流体シミュレーションで確認している. Fig. 4(b)は, $10 \mathrm{kT}$ の磁場に置かれたシリコンプラズマ から放射されるX線スペクトル(灰色破線)と磁場が印 加されていないシリコンプラズマから放射されるX線 スペクトル(黒実線)の比較である.

\section{6. まとめ}

レーザー駆動方式による強磁場発生によって, 高エネ ルギー密度科学が包含する学際的研究の幅が拡大した。 磁場によって，レーザー加速量子ビームの高品質化が図 られ，その実益は高速点火レーザー核融合における加熱 効率の向上に繋がっている. 今後は, レーザー加速イオ ンビームの高エネルギー化やこれまで加速させることが 難しかった高 $Z$ 番号イオンの加速にも繋がると期待し ている. 現在, レーザー駆動方式で達成出来ている磁場 強度は数キロ・テスラに留まっている。10 kT を達成す る事ができれば, 高エネルギー密度磁化プラズマに量子 論的な効果が加わることとなり, 更なる研究領域の拡大 が期待される. 我々は, スネール・ターゲット及び磁場 圧縮を使い, $10 \mathrm{kT}$ の達成を目指している.

\section{謝 辞}

本研究の遂行に当たり, レーザーオペレーション, ター ゲット製作，プラズマ計測及び計算機・ネットワークの 管理に支援を頂いた，大阪大学レーザー科学研究所及び サイバーメデイアセンターの職員各位に感謝申し上げま す. 本研究の一部は, 自然科学研究機構核融合科学研究
所との双方向型共同研究及びレーザー科学研究所の共同 利用・共同研究拠点事業の支援を得て実施されました。 同時に, 本研究の一部は日本学術振興会の科学研究費補 助金, 日露二国間交流事業, 特別研究員事業, 日米科学 技術協力事業核融合分野の支援も得て実施されました。

本研究を進める上で，貴重な知見を提供頂いた，兒玉 了祐氏 (大阪大学), 疇地 宏氏 (大阪大学), 千德 靖彦氏 (大 阪大学), 長友 英夫氏 (大阪大学)，佐野孝好氏 (大阪大 学), 城崎 知至氏(広島大学), 有川安信氏 (大阪大学), 重森 啓介氏 (大阪大学), 坂和 洋一氏 (大阪大学), 余語 覚文氏 (大阪大学), 蔵満 康浩氏 (大阪大学), Joao Jorge Santos 氏(ボルドー大学), Philippe Nicolai 氏(ボルドー 大学), Vladimir Tikhonchuk氏(ボルドー大学), 砂原淳 氏 (パデュー大学), 坂上 仁志氏(核融合科学研究所), Philipp Korneev 氏(ロシア国立核科学研究大学), Gabriel Schaumann 氏(ダルムシュタット工科大学), Zhe Zhang 氏(中国科学院物理学研究所), Jiayong Zhong 氏(北京師 範大学), John Moody 氏(ローレンスリバモア国立研究 所), Bradley Pollock氏(ローレンスリバモア国立研究 所), 荻津 格氏(ローレンスリバモア国立研究所), Frank Graziani 氏(ローレンスリバモア国立研究所)に感謝いた します。

最後にこのような機会を提供頂きましたレーザー研究 編集委員の皆様に感謝申し上げます。

\section{参考文献}

1) S. Fujioka, Z. Zhang, K. Ishihara, K. Shigemori, Y. Hironaka, T. Johzaki, A. Sunahara, N. Yamamoto, H. Nakashima,: T. Watanabe, et al.: Sci. Rep. 3 (2013) 1170.

2) P. Korneev, E. D' Humières, and V. Tikhonchuk: Phys. Rev. E 91 (2015) 043107

3) X. X. Pei, J. Y. Zhong, Y. Sakawa, Z. Zhang, K. Zhang, H. G. Wei, Y. T. Li, Y. F. Li, B. J. Zhu, T. Sano, et al.: Phys. Plasmas 23 (2016) 032125.

4) K. Matsuo, H. Nagatomo, Z. Zhang, P. Nicolai, T. Sano, S. Sakata, S. Kojima, S. H. Lee, K. F. F. Law, Y. Arikawa, et al.: Phys. Rev. E 95 (2017) 053204.

5) M. Bailly-Grandvaux, J. J. Santos, C. Bellei, P. Forestier-Colleoni, S. Fujioka, L. Giuffrida, J. J. Honrubia, D. Batani, R. Bouillaud, M. Chevrot, et al.: Nat. Commun. 9 (2018) 102.

6) S. Sakata, S. Lee, H. Morita, T. Johzaki, H. Sawada, Y. Iwasa, K. Matsuo, K. F. F. Law, A. Yao, M. Hata, et al.: Nat. Commun. 9 (2018) 3937.

7) J. J. Santos, M. Bailly-Grandvaux, M. Ehret, A. V. Arefiev, D. Batani, F. N. Beg, A. Calisti, S. Ferri, R. Florido, P. ForestierColleoni, et al: : Phys. Plasmas 25 (2018) 056705.

8) B. J. Zhu, Y. T. Li, D. W. Yuan, Y. F. Li, F. Li, G. Q. Liao, J. R. Zhao, J. Y. Zhong, F. B. Xue, S. K. He, et al.: Appl. Phys. Lett. 107 (2015) 261903.

9) C. Goyon, B. B. Pollock, D. P. Turnbull, A. Hazi, L. Divol, W. A. Farmer, D. Haberberger, J. Javedani, A. J. Johnson, A. Kemp, et al:: Phys. Rev. E 95 (2017) 033208.

10) K. F. F. Law, M. Bailly-Grandvaux, A. Morace, S. Sakata, K. Matsuo, S. Kojima, S. Lee, X. Vaisseau, Y. Arikawa, A. Yogo, et al.: Appl. Phys. Lett. 108 (2016) 091104.

11) H. Daido, F. Miki, K. Mima, M. Fujita, K. Sawai, H. Fujita, Y. Kitagawa, S. Nakai, and C. Yamanaka: Phys. Rev. Lett. 56 (1986) 846.

12) G.-Q. Liao, Y.-T. Li, B.-J. Zhu, Y.-F. Li, F. Li, M.-C. Li, X. Wang, Z. Zhang, S.-K. He, W.-W. Wang, et al.: Matter Radiat. Extrem. 1 (2016) 187.

13) C. Courtois, D. Ash, D. M. Chambers, R. D. Grundy, and N. C. Woolsey: J. Appl. Phys. 98 (2005) 054913. 
14) V. T. Tikhonchuk, M. Bailly-Grandvaux, J. J. Santos, and A. Poyé: Phys. Rev. E 96 (2017) 023202.

15) Z. Fu, L. Jia, X. Sun, and Q. Chen: High Energy Density Phys. 9 (2013) 781.

16) H. Morita, A. Sunahara, Y. Arikawa, H. Azechi, and S. Fujioka: Phys. Plasmas 25 (2018) 094505.

17) D. J. Strozzi, M. Tabak, D. J. Larson, L. Divol, A. J. Kemp, C. Bellei, M. M. Marinak, and M. H. Key: Phys. Plasmas 19 (2012) 072711.

18) H. Cai, S. Zhu, and X. T. He: Phys. Plasma 20 (2013) 072701.

19) T. Johzaki, H. Nagatomo, A. Sunahara, Y. Sentoku, H. Sakagami, M. Hata, T. Taguchi, K. Mima, Y. Kai, D. Ajimi, et al.: Plasma Phys. Control. Fusion 59 (2017) 014045.
20) L. J. Perkins, B. G. Logan, G. B. Zimmerman, and C. J. Werner: Phys. Plasmas 20 (2013) 072708.

21) H. Nagatomo, T. Johzaki, T. Asahina, M. Hata, K. Matsuo, S. Lee, A. Sunahara, H. Sakagami, K. Mima, K. Iwano, et al.: Nucl. Fusion 57 (2017) 086009.

22) A. J. Kemp, Y. Sentoku, and M. Tabak: Phys. Rev. Lett. 101 (2008) 075004.

23) A. Arefiev, T. Toncian, and G. Fiksel: New J. Phys. 18 (2016) 105011.

24) K. F. F. Law, Y. Abe, A. Morace, Y. Arikawa, S. Sakata, S. Lee, K. Matsuo, H. Morita, Y. Ochiai, C. Liu, et al.: arXiv:1904.02850v1 [physics.plasm-ph] (2019). 